Agriculture, Agrobusiness and Biotechnology

Vol.59: e16160485, January-December 2016 http://dx.doi.org/10.1590/1678-4324-2016160485 ISSN 1678-4324 Online Edition

AN INTERNATIONAL JOURNAL

\title{
Biotic Contamination and Possible Ways of Sterilization: A Review with Reference to Bamboo Micropropagation.
}

\author{
Syandan Sinha Ray ${ }^{1}$,Nasim $\mathrm{Ali}^{2 *}$. \\ ${ }^{I}$ Ramakrishna Mission Vivekananda University - Agricultural, Biotechnology, Howrah, West Bengal, India; \\ ${ }^{2}$ Bidhan Chandra Krishi Viswa Vidyalaya Faculty of Agriculture - Agricultural Biotechnology, Mohanpur Nadia \\ West Bengal, India.
}

\begin{abstract}
Multipurpose use of bamboo in rural life makes it as poor man's timber in Asian countries. Deforestation and industrialization leads to destruction of natural forest. To replenish, a rapid plantation of bamboo could be one of the possible solutions. Bamboo is propagated mainly by vegetative methods though it is not suitable for large scale plantation because of several limitations. Micropropagation is gaining importance for large scale propagation because of its capability in raising huge number of true to type propagules in a limited space in very short span of time. Like any other plant, the chief constraint of bamboo micropropagtion is in vitro contamination arises from several sources including explants. Most of the contaminants are reduced by maintaining aseptic conditions. The surface adhering microbial contaminant (Epiphytic) is usually checked by using several available surface sterilants. But the endophytic contaminant (present within the explants) is not easily controlled. Endophytic fungus could be controlled by using systemic fungicides but controlling bacteria is again more troublesome. Antibiotic with broad spectrum activity coupled with low phytotoxicity is prerequisite to get better results. Treatment duration and type of antibiotic are the critical factor to reduce the contamination. But unscientific use of antibiotic may lead to the development of resistant microbial strains. That is why antibiotic selection after identification of the contaminants may be an efficient way to counter this problem. The present review is done on use of antibiotic controlling bacterial contamination during micropropagation special reference to bamboo.
\end{abstract}

Key words: Biotic contamination, sterilization, bamboo, micropropagation

*Author for correspondence: nasimali2007@gmail.com

Braz. Arch. Biol. Technol. v.59: e160485 Jan/Dec 2016 
Ray, SS et al.

\section{INTRODUCTION}

Bamboo is considered as the fastest growing perennial, evergreen plant belonging to subfamily Bambusoideae under the family Poaceae ${ }^{1,2}$. Multipurpose utility of bamboo made it 'My brother' in Vietnamese, in Chinese it is called as 'Friend of the people' and in India it is known as 'Green gold" or 'Poor man's timber'. In spite of several economic importance, the productivity is less in India than china and most of bamboo stock are available from natural forest ${ }^{4}$. Reduction of natural forest is increasing day by day due to uncontrolled deforestation and human activities such as industrialization ${ }^{5}$. So, the multiplication and conservation of the bamboo species in its natural environment is urgently needed ${ }^{6}$. Bamboo is propagated through either of seed or vegetative methods ${ }^{7}$ though both methods have several disadvantages. Seed based propagation is limited due to long and unpredictable flowering cycle, poor seed setting, short seed dormancy period, high seed sterility, low seed viability, high seed-borne infections ${ }^{8}$. Vegetative propagation method has also several disadvantages such as bulkiness of cutting materials ${ }^{9,10,11}$, seasonal dependency ${ }^{12}$ and low multiplication rate ${ }^{13}$. Plant tissue culture is already proved as a reliable tool to produce large number of genetically identical plant in vitro condition ${ }^{14}$. So bamboo propagation by plant tissue culture method and its plantation in natural environment are essentially becoming an alternative way to restore the forest in natural environment. Like any technique, the micropropagation has also limitations besides its several advantages. Though juvenile plants are more suitable than matured plant for micropropagation ${ }^{15}$ but both of adult and juvenile plants are suitable for tissue culture of bamboo ${ }^{11,16}$. The adult explants have several problems like endogenous contamination ${ }^{16}$, low growth rate and rooting 17, 18,19 . Contamination, especially biotic i.e. fungal and bacterial contaminations, is considered as single most important damaging factor of in vitro culture of plants $20,21,22$. The present review was aimed to address those contaminants and its possible ways of eradication with special reference to micro-propagation of bamboo.

\section{BIOTIC CONTAMINATION IN PLANT TISSUE CULTURE}

Microbial contaminants may arises from different sources like infected plant

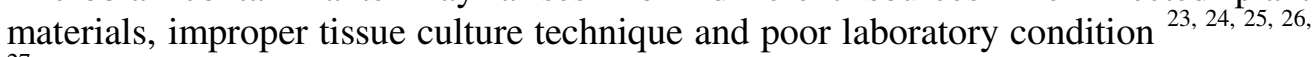
27. Explant contamination is related to several factors like source of explants and environment ${ }^{21}$. Fungal and bacterial contamination is one of the serious problems for the micro-propagation of woody plant species 28, 29, 30. Among fungal contamination, presence of systematic fungal contamination is the most problematic issue of micropropagation of mature woody species ${ }^{31}$. The fungal contamination was considered as most predominant factor in B. balcooa during tissue culture ${ }^{29}$. Fungal contamination may also arises from explants itself or air or during culture ${ }^{31,32}$, also associated to the indoor air, tables/walls, and human skin ${ }^{33}$. On the contrary, the latent contamination of bacteria is the most problematic issue for in vitro propagation of several species of Bambusa ${ }^{30}$. In plant like bamboo, the nodal explants have large intercellular spaces, which are exposed during cutting before surface sterilization and promote the entry of bacterial and fungal spores into explant. As a result they are unable to control by the surface sterilization protocol and further found as contamination advance stages in medium ${ }^{34}$. These microorganisms are competing adversely with plant for their growth since the media considered as good nutrient source for them ${ }^{20}$. Presence of this microorganisms leads to increase of plant mortaltity, create variation in growth (reduction of shooting proliferation and rooting), tissue necrosis even plant death ${ }^{35}$. 


\section{EPIPHYTIC VS ENDOPHYTIC}

The contaminant in culture media may have immediate or latent expression in which it remains dormant for long time ${ }^{36}$. Epiphytic bacteria live on plant surfaces ${ }^{37}$ and can be removed through chemical disinfectants. In contrast, the endophytic microbes i.e., microbes that colonize living, internal tissues of plants, without causing any immediate negative effect ${ }^{38,39}$ and are not easily eliminated by simple surfacesterilization methods ${ }^{36,40,41}$. For this reason the existing contaminants are generally controlled by using either antibiotic or fungicide ${ }^{42,43,44}$. That is why the antibiotic therapy is getting much importance to solve this problem ${ }^{45}$. Now a day, there are several alternative ways to control the contaminants reported by several authors such as through light and heat ${ }^{46}$, micro wave and hot water treatment ${ }^{47}$. But till now most researchers depends on chemicals to control the contaminants during in vitro propagation of plant.

\section{SELECTION OF ANTIBIOTIC}

Elimination of the latent contamination in culture may be done by using several antibiotics. But type, application and treatment duration of antibiotics vary plant to plant $^{48}$. In general antibiotics are broadly classified into two groups i.e; bactericidal (kills bacteria) and bacteriostatic (prevent bacterial growth). Several researchers experimentally proved that the uses of bactericidal are more advantageous over bacteriostatic antibiotic to control the endophytic contamination if there is no side effect of antibiotics in explants ${ }^{49,50,51}$. An ideal antibiotic in such case should be attributed as stable, easily soluble in nature, not affected by components and $\mathrm{pH}$ of the medium, lacks side effects, broadly active, non-resistance inducing, inexpensive and non-toxic to humans ${ }^{52,53}$. But tremendous use of antibiotics is not recommended because of its phytotoxicity and selection for resistance strains ${ }^{44}$. Since most of antibiotics have narrow target range for bacteria, combination of antibiotics were found better to reduce contamination as well as damaging plants due to their synergistic effect ${ }^{54}$. But antibiotic having broad range of target may shown better response than the combination of antibiotics ${ }^{55}$. Similar to antibiotic, idle fungicide should be nontoxic to plant cell and broad spectrum fungicidal activity ${ }^{56}$. Since continuous use of single antibiotic often leads to antibiotic resistant microbial contaminants on culture, combination of different antibiotics is better option to counter the problem ${ }^{41,51}$. This approach if suitable to solve the problem then there is a need of modification in concentration of antibiotics to lowering down the phytotoxicity level of antibiotic on plant since effective concentration for both antibiotic may affect the plant ${ }^{51}$. Combination of antibiotics will kill contaminants without damaging the plant. Use of combination of bactericides in bamboo/woody plants tissue culture, which has limited uses of antibiotics, may be propoted to avoid the unwanted effect of microbial contaminants on the growth of plant.

\section{ANTIBIOTIC IN MODERN ERA}

Till now several attempts have been taken to reduce the contamination using the antibiotics. But it has several problems. Removal of bacteriostatic effect of antibiotic leads to continue the growth of bactetia ${ }^{52,57,58,53}$. Besides that rapid use of antibiotic may leads to phytotoxicity ${ }^{59}$ and development of resistant microbial strains ${ }^{60,61}$. Long duration exposure of cells or tissues to antibiotics may also leads to change in genetic makeup of organelles (the cytoplasmic genes or cytoplasmic DNA) as well 
as development of resistance in bacterial cells ${ }^{62}$. Therefore characterization of contaminants (type) before the antibiotic therapy is right way to counter the problem since it may leads to appropriate selection of antibiotic. This method is reported by several authors for several plants including; Hazelnut ${ }^{41}$, Withania somnofera, Piper nigram, Piper colubrium and taxus Baccatasub sp., Wallichiana ${ }^{61}$; Jatropha curcus ${ }^{63}$, including bamboo (Guadua angustifolia Kunth) ${ }^{64}$. Use of Plant Preservative Mixture $^{\mathrm{TM}}$ (PPM) (Plant Cell Technology, Washington, D.C.) is also an alternative option to control the contamination reported by several authors. This chemical is mixture up of methylchloloisothiazolone and methylisothiazolone ${ }^{44}$, is a biocide compound, heat stable and effective against a wide spectrum of common in vitro contaminants ${ }^{65}$. PPM is effective against both bacteria and fungi and unlike conventional antibiotics, can be autoclaved in the media ${ }^{66}$. These characteristics of PPM make it an attractive alternative to using conventional antibiotics and fungicides in plant tissue culture. Antibiotics as media components are also reported in bamboo (Guadua angustifolia Kunt) ${ }^{67}$.

\section{EDAPHIC FACTORS VIS-À-VIS CONTAMINATION}

It is evident from several literatures that the chance of contamination during in vitro culture and seasons for collecting explants has a strong positive correlation. Explant collected at rainy season is having higher bud breaking coupled with high chances of contamination. More than $60 \%$ endogenous contamination during rainy season reported in B. nutans ${ }^{68}$. Collection of nodal explants (Arundinaria callosa Munro) during rainy season showed $30 \%$ more contaminations than that of after monsoon season ${ }^{69}$. Quite similar results were reported in D. asper ${ }^{70,71}$; in D. hamiltonii ${ }^{72}$ and in $D$. giganteus ${ }^{73}$. It could be suggested to avoid collection of explant during rainy season.

\section{SURFACE STERILANTS FOR BAMBOO TISSUE CULTURE}

Bamboo micropropagation most widely used surface sterililants are Bavistin and Mercuric chloride. Sodium or Calcium hypochloride and Hydrogen peroxide are also reported by several workers for several bamboo species. Mercuric chloride $(0.1 \%)$ was found better than Sodium hypochloride $(0.05,0.1$ and $0.2 \%)$ in B. tulda ${ }^{74}$ after treatment of 10 minutes. Treatment of 20 minutes under Mercuric chloride $(0.2 \%)$ was found better than 10-20 minutes treatment of Calcium hypochloride in D.strictus ${ }^{8}$. $0.1 \%$ Mercuric chloride was better than Sodium hypochloride (2\%) and Hydrogen peroxide $(10 \%)$ in B. Ventricosa (treatment durations were not same for this treatments) ${ }^{75}$. Similar report in other plant reported in nodal explants of Aconitum heterophyllum ${ }^{76}$. They found $0.1 \%$ Mercuric chloride was superior over Hydrogen peroxide (10\%) and Sodium hypochloride (1.5\%). Although, the treatment with high concentration $(0.2 \%)$ of Mercuric chloride for 10-15 minutes increased the chance of aseptic culture in $D$. strictus ${ }^{77}$, it reduces the bud breaking percentage of plant reported in $B$. wamin $^{78}$. On the contrary, lower duration of $0.1 \%$ Mercuric chloride increases high survival rate in $B$. ventricosa ${ }^{75}$. Pretreatment of Bavistin on nodal explants reduces the chance of fungal contamination in G. atroviolaceae ${ }^{79}$. Negative impact of Calcium hypochloride as surface sterilant (discolorization of plant) in Guadua angustifolia Kunth reported by ${ }^{67} .1 \%$ Bavistin is reported as most widely used concentration as surface sterilants during in vitro propagation of bamboo. Though there are exceptions also, Bavistin reported @ 0.1\% in Bambusa nutans Wall ${ }^{68} ; 0.5 \%$ in B.nutans ${ }^{80} ; 0.2 \%$ in D. strictus ${ }^{81}$. Besides Bavistin, other fungicides that are reported till date as surface sterilants for in vitro propagation of bamboo are Benomyl and Mancozeb. Though Bavistin and Benomyl are made up of 
Endophytic bacterial contamination in vitro

same active component benzimidazole but Benomyl is considered as most effective chemical to control fungal contamination ${ }^{22}$. Use of this chemical are very limited in comparsion to Bavistin for in vitro propagation of different bamboo species; Benlate (benomyl) @1 gm/l reported in D.giganteus and B.vulgaris ${ }^{82}$; as media component in Dendrocalamus giganteus Munro ${ }^{73}, 0.1 \%$ in Bambusa vulgaris 'Striata' ${ }^{83}$, in Guadua angustifolia@ $2 \mathrm{~g} / \mathrm{l}^{67}$. Mancozeb is reported @ $0.1 \%$ in B. balcooa ${ }^{84}, B$. nutans @ $0.1 \%{ }^{85}$. The duration of surface sterilization that depends on the size and nature of explants has significant role in the success rate of macropropagation. Effect of sterilization is depending on several factors such as sterilization type, concentration and time of treatment with the sterilizing agent ${ }^{86}$. The reduction of contamination may vary from species to species and also depends on the chemicals which are used. During surface sterilization, the cutting ends are entry point of the active compound of the surface sterilant, so profound penetration of the chemicals results toxic effect on explants and slow down the growth of plant ${ }^{34}$. This entire chemical fruitfully eradicates the surface contaminations but has limitation in controlling the endophytic contamination. Now a day, the antibiotics are also being used during surface sterilization.

\section{ANTIBIOTIC AS SURFACE STERILANTS IN BAMBOO}

Microbial contamination using antibiotics are reported by several workers during in vitro propagation of different plants i.e; Rubber (HeveabrasiliensisMuell.Arg) ${ }^{87}$, Hazelnut ${ }^{41}$, Withania somnofera, Piper nigram, Piper colubrium and taxus Baccata subsp., Wallichiana ${ }^{61}$, Jatropha curcus $^{63}{ }^{6}$, Banana ${ }^{88}$, Orange tree i.e; Citrus sinensis L. Osbeck cv. Madame Vinous and Sweet orange trees i.e; C. sinensis cv. Valencia ${ }^{28}$. In bamboo, attempts have been taken to reduce the endophytic contamination during in vitro propagation using antibiotics as surface sterilant. Agri-mycin and Benomyl in Guadua angustifolia ${ }^{67}$, mixture of Gentamycine and Mancozeb ${ }^{84}$, mixture of Bavistine and Bacteriomycine ${ }^{89}$, Germicide, Teepol and savlon ${ }^{90}$ for B.balcooa, Streptomycin Sulfate for B. nutans ${ }^{68}$, D.membranaceus Munro ${ }^{91}$, Streptomycin and Kanamycin for Dendrocalamus giganteus ${ }^{92}$,Mancozeb and Streptomycin Sulphate in B.nutans ${ }^{85}$ were reported as surface sterilant during in vitro proapagation of these species. Use of Streptomycin, Riffampicin, Streptocyclin, Ciprofloxacinwas reported by ${ }^{30}$ to control contamination during in vitro propagation of different bamboo species like B. tulda, B. waminand B. balcooa. There was only one report ${ }^{64}$ who used Kanamycin and streptomycin sulfate as media component during multiplication of Guadua angustifolia Kunth. All the earlier works, researchers used broad spectrum antibiotics for decontamination. Reports on application of antibiotic after identifying the bacteria,are available in case of Ilex dumosa $^{55}$, Aglaonema ${ }^{27}$, Guadua angustifolia Kunth ${ }^{64}$. No attempts have been taken to use antibiotic after identifying bacteria in bamboo (except in Guadua angustifolia Kunth). In the era of genomics, bacteria and fungus may easily be identified by using the molecular techniques. It may be suggested to use antibiotics during micropropagation after proper identification of the endophytes to get substantial results. The conserved sequence in $16 \mathrm{~S}$ rDNA for bacteria and Internal transcribed spacer (ITS) sequence for Fungus may be utilized for identification and there by antibiotic may be selected for its eradication.

\section{CONCLUSION}


The endophytic contaminants are serious concern in micropropagation. Presence of contaminants in culture affects the growth of plant in vitro. Plant tissue culture is an expensive method, so contamination frees cultures are need to be developed to get desirable profit. There several antibiotics were already reported by several authors to eliminate the endophytic contaminants during tissue culture of many plants due to failure of general sterilization method. Antibiotic as a media component is more effective as evident from the report of earlier workers on different plants. But addition of antibiotic within media may lead to phytotoxic effect on plant. So, broad spectrum antibiotic with low phytotoxicity is only desirable to eliminate the endophytic contaminants. For this reason there need to find out the minimum inhibitory concentration of antibiotic against particular microorganisms after its proper identification using the most reliable molecular technique like 16S rDNA. There need further research work particularly on bamboo since each antibiotic has different mode of action, solubility etc.

Table 1: Antibiotics used in bamboo tissue culture

\begin{tabular}{|c|c|c|c|c|}
\hline Bamboo species & Antibiotic & Concentration & $\begin{array}{l}\text { Duration } \\
\text { (Minutes) }\end{array}$ & $\begin{array}{l}\text { Reported } \\
\text { by }\end{array}$ \\
\hline \multirow[t]{2}{*}{ B.balcooa } & Gentamycine & $0.1 \%$ & $\begin{array}{l}\text { Depending upon } \\
\text { the collection } \\
\text { time. }\end{array}$ & \\
\hline & Bacteriomycine & $0.5 \%$ & 15 minutes & 89 \\
\hline \multirow[t]{2}{*}{ B. nutans } & Streptomycin Sulfate & $0.05 \%$ & $20-25$ minutes & 68 \\
\hline & Streptomycin Sulphate & $0.1 \%$ & 5 minutes & 85 \\
\hline $\begin{array}{l}\text { Dendrocalamus } \\
\text { giganteus }\end{array}$ & $\begin{array}{l}\text { Streptomycin and } \\
\text { Kanamycin }\end{array}$ & $\begin{array}{l}\text { Streptomycin } 0.01 \\
\%(\mathrm{w} / \mathrm{v}), \\
\text { Kanamycin } 0.05 \% \\
(\mathrm{w} / \mathrm{v})\end{array}$ & 30 minutes & 92 \\
\hline D.membraneous & Streptomycin Sulfate & $0.25 \%$ & 45 minutes & 91 \\
\hline $\begin{array}{l}\text { Guadua } \\
\text { angustifolia }\end{array}$ & $\begin{array}{l}\text { 1.Agri-mycin } \\
\text { (Surface sterilants). } \\
2 . \quad \text { PPM (Media } \\
\text { component) }\end{array}$ & $\begin{array}{l}2 \mathrm{gm} / \mathrm{l} \\
2 \mathrm{ml} . / 1\end{array}$ & 10 minutes & 67 \\
\hline $\begin{array}{l}\text { Guadua } \\
\text { angustifolia } \\
\text { Kunth }\end{array}$ & $\begin{array}{l}\text { Kanamycin and } \\
\text { streptomycin sulphate }\end{array}$ & $10 \mu \mathrm{g} / \mathrm{ml}$ each & $\begin{array}{l}\text { Act as media } \\
\text { component }\end{array}$ & 64 \\
\hline
\end{tabular}

\section{REFERENCES}

1. Kigomo BN. Distribution, cultivation and research status of bamboo in Eastern Africa. KEFRI EcolSerMonogr.1988; 1:1-19.

2. Yeasmin L, Ali NM, Gantait S, Chakraborty S. Bamboo: an overview on its genetic diversity and characterization. 3 Biotech.2014; 5 (1): 1-11.

3. Behari B. Status of Bamboo in India. Compilation of papers for preparation of national status report on forests and forestry in India. Survey and Utilization Division, Ministry of Environment and Forest. 2006; 109-120.

4. Agnihotri KA, Nandi KS. In vitro shoot cut: A high frequency multiplication and rooting method in the bamboo Dendrocalamus hamiltoni. Biotech. 2009; 8: 259-263.

5. Ray SS, Ali MN. Evaluation of Inexpensive Bedding Materials for Culm Cutting of Bambusa balcooa Roxb. and Its Field Performance. J Biotechnol Biomater. 2016 ; 6: 227. doi:10.4172/2155-952X.1000227.

6. Roy SS, Ali MN, Gantait S, Chakraborty S, Banerjee M. Tissue Culture and Biochemical Characterization of Important Bamboos. Res. J. Agri.Sci. 2014; 5(2): 135-146.

7. Saxena S. In vitro propagation of the bamboo (Bambusa tulda Roxb.) through shoot proliferation. Plant Cell Rep.1993; 9:431-434. 
Endophytic bacterial contamination in vitro

8. Pandey BN, Singh NB. Micropropagation of Dendrocalamus strictus nees from mature nodal explants. Journal of Applied and Natural Science. 2012; 4 (1): 5-9.

9. Arya S, Satsangi R, Arya ID. Rapid mass multiplication of edible bamboo Dendrocalamus asper. J Sustain For. 2002; 4:103-109.

10. Arya S, Sharma S, Kaur R, Arya ID. Micropropagation of Dendrocalamus asper by shoot proliferation using seeds. Plant Cell Rep .1999;18:879-882.

11. Singh SR, Singh R, Kalia S, Dalal S, Dhawan AK, Kalia RK. Limitations, progress and prospects of application of biotechnological tools in improvement of bamboo-a plant with extraordinary qualities. Physiol Mol Biol Plants. 2013;19(1):21-41.

12. Saxena S, Bhojwani SS. In vitro clonal multiplication of 4-year old plants of the bamboo Dendrocalamus longispathus Kurz. In Vitro Cell DevBiol Plant.1993; 29:135-142.

13. Banerjee M, Gantait S, Pramanik BR. A two step method for accelerated mass propagation of Dendrocalamus asper and their evaluation in field. Physiol MolBiol Plants. 2011; 17(4):387-393.

14. Aitken - Christie J, Toyoki K, Shinsaku T. Automation and environmental Control in plant tissue culture- General Introduction and overview. Aitken Christie J, Kozai T, M. Lila Smith (eds.), Automation and Environmental Control In plant tissue culture. Kluwer Academic Publishers. 1995.

15. Giri CC, Shyamkumar B, Anjaneyulu C. Progress in tissue culture, genetic transformation and applications of biotechnology to trees: an overview. Trees.2004; 18:115-135.

16. Gielis J, Oprins J. Micropropagation of temperate and tropical woody bamboos-from biotechnological dream to commercial reality. Bamboo for sustainable development. Proceedings of the 5th International Bamboo Congress and the 6th International Bamboo Workshop, San Jose, Costa Rica. pp 333-344.2002.

17. Nadgir AR, Phadke CH, Cupta PK, Parsharami VA. Rapid multiplication of bamboo by tissue culture. Silvae Genet.1984; 33:219-233.

18. Prutpongse P, Gavinlertvatana P. In vitro micropropagation of 54 species from 15 genera of bamboo. Hortscience.1992; 27:453-454.

19. Chaturvedi HC, Sharma M, Sharma AK. In vitro regeneration of Dendrocalamus strictus Nees through nodal segments taken from field-grown culms. Plant Sci .1993; 91:97-101.

20. Omamor IB, Asemota AO, Eke CR, Eziashi EI. Fungal contaminants of the oil palm tissue culture in Nigerian Institute For Oil Palm Research (NIFOR). African J. Biotechnol .2007; 2 (10): 534-537.

21. Singh V, Tyagi A, Chauhan PK, Kumari P, Kaushal S. Identification And Prevention Of Bacterial Contimination On Explant Used In Plant Tissue Culture Labs. International Journal of Pharmacy and Pharmaceutical Sciences.2011; 3 (4):160-161.

22. Ahmadi E, Nasr SMH, Jalilvand H, Savadkoohi SK. Contamination control of microbe Ziziphusspina [christti] seed in vitro culture, Trees. 2012; 126 (4):1299-1304.

23. Mizra MS, Ahmad W, Latif F, Haurat J, Bally R, Normand P, Malik KA. Isolation, partial characterization, and the effect of plant growth-promoting bacteria (PGPB) on micropropagated sugarcane in vitro. Plant Soil . 2001; 237:47-54.

24. Lata H, Li XC, Silva B, Moraes RM, Halda-Alija L. Identification of IAA-producing endophytic bacteria from micropropagated Echinaceae plants using 16S rRNA sequencing. Plant Cell Tissue Organ Cult. 2006; 85:353-359.

25. Shen H, Li Z, Han D, Yang F, Huang Q, Ran L. Detection of indigenous endophytic bacteria in Eucalyptus urophylla in vitro conditions. Front Agric China.2010; 4:37-41.

26. Thomas P, Goplakrishnan C, Krishnareddy M. Soft rot inciting Pectobacterium carotovorum (syn. Erwiniacarotovora) is unlikely to be transmitted as a latent pathogen in micropropagated banana. Plant Cell Tissue Organ Cult. 2011; 105: 423-429.

27. Fang JY, Hsu YR. Molecular identification and antibiotic control of endophytic bacterial contaminants from micropropagated Aglaonema cultures. Plant Cell Tissue Organ Cult.2012; 110 (1):53-62.

28. Niedz RP, Bausher MG. Control of in vitro contamination of explants from greenhouseand field-grown trees. In Vitro Cell Dev Biol Plant. 2002; 38: 468-471. 
29. Das M, Pal A. Clonal Propagation and Production of Genetically Uniform Regenerants from Axillary Meristems of Adult Bamboo. Plant Biochemistry \& Biotechnology. 2005; 14: $185-188$.

30. Abdulminam, Ali H, Nirmala C, Sharma ML. Control of in vitro contamination in bamboos, $P C M B$ 10(3\&4). 2009.

31. Ankur V, Meena B, Harsh NSK. Identification and Bioassay of Fungal Contaminants Observed During In Vitro Propagation Of Saracaasoca (Roxb.) De Wilde. Biotech. Int. 2014; 7(2): 35-42.

32. Babaolu M, Yorgancilar M, Akbudak MA. Dokukültürü: Temellaboratuarteknikleri (Plant tissue culture: Basic laboratory techniques).- In: Babaolu M, Gürel E, Özcan S (eds), BitkiBiyoteknolojisi: DokuKültürüveUygulamaları (Biotechnology of Plant: Plant Tissue Culture and Application). SelçukÜniversitesiVakfiYayınları-Konya- pp.1-35.2001.

33. Odutayo OI, Amusa NA, Okutade OO, Ogunsanwo YR. Sources of microbial contamination in tissue culture laboratories in southwestern Nigeria. African $J$. Biotechnol. 2007; 2: 67-72.

34. Thakur R, Sood A. An efficient method for explant sterilization for reduced contamination. Plant Cell Tissue and Organ Cult. 2006; 84: 369-371.

35. Kane M. Bacterial And Fungal Indexing Of Tissue Cultures. http://www.hos.ufl.edu/mooreweb/TissueCulture/class1/Bacterial\%20and\%20fungal\%20i ndexing\%20of\%20tissue\%20cultures. Doc

36. Leifert C, Cassells AC. Microbial hazards in plant tissue and cell cultures. In Vitro Cell Dev Biol Plant . 2001; 37(2): 133-138.

37. Hirano SS, Upper CD. Population biology and epidemiology of Pseudomonas syringae. Annu Rev Phytopathol.1990; 28:155-177.

38. Bacon CW, White JF Jr (eds). Microbial endophytes. Marcel- Dekker, New York, 487 pp,2002. ISBN 0-8247-8831-1.

39. Sette LD, Passarini MRZ, Delarmelina C, Salati F, Duarte MCT. Molecular characterization and antimicrobial activity of endophytic fungi from coffee plants. World J MicrobiolBiotechnol.2006. 22:1185-1195.

40. Attree SM, Sheffield E. An evaluation of ficoll density gradient centrifugation as a method for eliminating microbial contamination and purifying plant protoplasts. Plant Cell Rep.1986; 5:288-291.

41. Reed BM, Buckley PM, Dewilde TN. Detection and eradication of endophytic bacteria from micropropagated mint plants. In Vitro Cell Dev Biol Plant .1995; 31(1): 53-57.

42. George EF. Plant Propagation by Tissue Culture, Part 1, Techonology, England: Exegetics Ltd., pp. 121-145.1993.

43. Herman EB. Recent advances in plant tissue culture, IV: Microbial contamination of plant tissue cultures., Mohegan Lake, N.Y. AgritechConsultants.1996.

44. Niedz R. Using isothiazolone biocides to control microbial and fungal contaminants in plant tissue cultures. HortcTechnol.1998; 8:598-601.

45. Mathias PJ, Alderson PG, Leakey RRB. Bacterial contamination in tropical hardwood cultures. Acta Horticulture. 1987; 212: 43-48.

46. Sen MK, Hassan MM, Nasrin S, Jamal MAHM., Mamun-Or Rashid ANM, Dash BK . In vitro sterilization protocol for micropropagation of Achyranthesaspera L. node. Int. Res. J. Biotechnol. 2013;4: 89-93.

47. James RL, Gilligan CJ, Dumroese RK, Wermy DL. Microwave treatments to eradicate seed borne fungi on Douglas-fir seed. USDA Forest Service, Forest Pest Management, Report 88-7.

48. Reed BM, Mentzer J, Tanprasert $\mathrm{P}$, Yu X. Internal bacterial contamination of micropropagated hazelnut: identification and antibiotic treatment. Plant Cell Tissue Organ Cult . 1998. 52:67-70.

49. Young PM, Hutchins AS, Canfield ML. Use of antibiotics to control the bacteria in shoot cultures of woody plants. Plant Sci. Lett. Repo. 1984. 34: 203-209.

50. Fisse J, Batalle A, Pera J. Endogenous bacteria elimination in ornamental plants. Acta Horticulturae. 1987; 212:87-90.

51. Leifert C, Camotta H, Waites WM. Effect of combinations of antibiotics on micropropagated Clematis, Delphinium, Hosta, Iris and Photinia. Plant Cell Tissue Organ Cult .1992; 29:153-160. 
Endophytic bacterial contamination in vitro

52. Falkiner FR. The criteria for choosing an antibiotic for control of bacteria in plant tissue culture. Newsletter International Association for Plant Tissue Cult. 1990; 60: 13-23.

53. Mbah EI, Wakil SM. Elimination of bacteria from in vitro yam tissue cultures using antibiotics. Journal of Plant Pathology.2012; 94(1): 53-8.

54. Altan F, Bürün B, Sahin N. Fungal contaminants observed during micropropagation of Lilium candidum L. and the effect of chemotherapeutic substances applied after sterilization. African J. Biotechnol. 2010; 7: 991-995.

55. Luna C, Collavino M, Mroginski L, Sansberro P. Identification and control of bacterial contaminants from Ilex dumosa nodal segments culture in a temporal immersion bioreactor system using 16S rDNA analysis, Plant Cell Tissue Organ Cult . 2008; 95:1319.

56. Shields R, Robinson SJ, Anslow PA. Use of fungicides in plant tissue culture. Plant Cell Rep. 1984; 3: 33-36.

57. Falkiner FR. Antibiotics in plant tissue culture and micro propagation: What are we aiming at? In: Cassells A.C. (ed.). Pathogen and Microbial Contamination Management in Micro Propagation, 1997

58. Barrett C, Cassels AC. An evaluation of antibiotics for the elimination of Xanthomona scampestrispv. pelargonii (Brown) from Pelargonium domesticum cv. Grand slam. Plant Cell Tissue Organ Cult. 1994;36: 169-175.

59. Pollock KD, Barfield G, Shields R. The toxicity of antibiotics to plant cell cultures. Plant Cell Rep. 1984; 2: 36-39

60. Leifert C, Ritchie JY, Waites WM. Contaminants of plant-tissue and cell Cultures. World J MicrobiolBiotechnol.1991; 7:452-469

61. Kulkarni AA, Kelkar SM, Watve MG, Krishnamurthy KV. Characterization and control of endophytic bacterial contaminants in vitro cultures of Piper spp., Taxusbaccata subsp. wallichiana, and Withaniasomnifera. Can J Microbiol.2007; 53:63-74.

62. Abdi GR, Salehi H, Khosh-Khui M. Nano silver: a novel nanomaterial for removal of bacterial contaminants in valerian (Valerianaofficinalis L.) tissue culture. Acta Physiology Plant. 2008; 30: 709-714.

63. Misra P , Gupta N, Toppo DD, Pandey V, Mishra VK, Tuli R. Establishment of longterm proliferating shoot cultures of elite Jatropha curcas L. by controlling endophytic bacterial contamination. Plant Cell Tissue Organ Cult . 2010;100:189-197

64. Nadha HK, Salwan R, Kasana RC, Anand M, Sood A. Identification and elimination of bacterial contamination during in vitro propagation of Guadua angustifolia Kunth. Pharmacogn Mag. 2012. http://www.ncbi.nlm.nih.gov/pmc/articles/PMC3371444

65. Guri AZ, Patel KN, Compositions and methods to prevent microbial contamination of plant tissue culture media.1995. US patent 5,750,402

66. George MW, Tripepi RR. Plant Preservative Mixture (TM) can affect shoot regeneration from leaf explants of chrysanthemum, European birch, and rhododendron. Hortscience.2001; 36(4):768-769

67. Jime'nez, VM, Castillo J, Tavares E, Guevara E, Montie M. In vitro propagation of the neotropical giant bamboo, Guadua angustifolia Kunth, through axillary shoot proliferation. Plant Cell Tissue Org Cult. 2006; 86:389-395

68. Mehta R, Sharma V, Sood A, Sharma M, Sharma RK . Induction of somatic embryogenesis and analysis of genetic fidelity of in vitro derived plantlets of Bambusa nutans Wall. using AFLP markers. Eur J Forest Res. 2011; 130:729-736

69. Devi SW, Sharma GJ. In Vitro Propagation of Arundinaria callosa Munro- an Edible Bamboo from Nodal Explants of Mature Plants. The Open Plant Science Journal.2009; 3: 35-39.

70. Nadha HK, Kumar R, Sharma RK, Anand M, Sood A. In vitro propagation of Dendrocalamus asper and testing the clonal fidelity Using RAPD and ISSR markers, International Journal of Current Research, 2013; 5:2060-2067.

71. Singh SR, Dalal S, Singh R, Dhawan AK, Kalia RK. Micropropagation of Dendrocalamus asper (Schult. \&Schult. F. Backer ex K Heyne): an exotic edible bamboo. J Plant BiochemBiotechnol. 2012b; 21:220-228. 
72. Singh SR, Dalal S, Singh R, Dhawan AK, Kalia RK. Seasonal influences on in vitro bud break in Dendrocalamus hamiltonii Arn. ex Munro nodal explants and effect of culture microenvironment on large scale shoot multiplication and plantlet regeneration. Indian $J$ Plant Physiol.2012a; 17:9-21.

73. Ramanayake SMSD, Yakandawala K. Micropropagation of the giant bamboo (Dendrocalamus giganteus Munro) from nodal explants of field grown culms. Plant Sci . 1997; 129:213-223.

74. Mishra Y, Patel PK, Yadav S, Shirin F, Ansari SA. A micropropagation system for cloning of Bambusa tulda Roxb. SciHortic.2008;115:315-318.

75. Wei Q, Cao J, Qian W, Xu M, Li Z, Ding Y. Establishment of an efficient micropropagation and callus regeneration system from the axillary buds of Bambusa ventricosa. Plant Cell Tissue Organ Cult. 2015; 122:1-8.

76. Srivastava N, Kamal B, Sharma V, Negi YN, Dobriyal AK, Gupta S, Jadon VS. Standardization of Sterilization Protocol for Micropropagation of Aconitum heterophyllum- An Endangered Medicinal Herb. Academic Arena.2010; 2(6): 62-66

77. Kapruwan S, Bakshi M, Kaur M. Rapid In Vitro Propagation Of The Solid Bamboo, Dendrocalamus StrictusNees, through Axillary Shoot Proliferation. Biotechnology International.2014; 7 (3): 58-68.

78. Arshad SM, Kumar A, Bhatnagar SK. Micropropagation of Bambusa wamin through proliferation of mature nodal explants. J Biol Res.2005; 3:59-66

79. Bisht P, Pant M, Kant A. In vitro propagation of Gigantochloa atroviolaceae Widjaja through nodal explants. JAmSci . 2010; 6:1019-1026.

80. Sharma P, Sarma KP. In vitro Propagation of Bambusa nutan in commercial scale in Assam, India. J. Environ. Res. Develop 2014;.9(2):348-355.

81. Chowdhury P, Das M, Sikdar SR, Pal A. Influence of the physiological age and position of the nodal explants on the micropropagation of field grown Dendrocalamus Strictusnees. PCMB . 2004; 5(1\&2) : 45-50.

82. Ramanayake SMSD, Yakandawala K, Nilmini PKD, Ikbal MCM. Studies on Micropropagation of Dendrocalamus gigateus and Bambusa vulgaris var. striata. In: Bamboo, People and The Environment, vol.1. Propagation and Management. INBAR Tech Rep 8: 75-85.1995.

83. Ramanayake SMSD, Meemaduma VN, Weerawardene TE . In vitro shoot proliferation and enhancement of rooting for the large scale propagation of yellow bamboo (Bambusa vulgaris 'Striata'). SciHortic. 2006; 110:109-113.

84. Mudoi DK, Borthakur M. In vitro micropropagation of Bambusa Balcooa Roxb. through nodal explants from field -grown culms and scope for upscaling. Current Science.2009; 96: 962-966.

85. Modui KD, SP Saikia, Borthakur M. Effect of nodal position, seasonal variation, shoot clump and growth regulators on micropropagation on commercially important bamboo Bamusa nutans well. ex. Munro.. African J. Biotechnol .2014; 13(19); 1961-72.

86. Roxas NJL, Tashiro Y, Miyazaki S, Isshiki S, Takeshita A. In vitro Propagation of Higo Chrysanthemum (Dendranthema x grandiflorum (Ramat.) Kitam.); Bull. Fac, Agr., Saga Univ. 80 : 57-67.1997.

87. Wilson ZA, Power JB. Elimination of systemic contamination in explant and protoplast cultures of rubber (HeveabrasiliensisMuell,Arg.). Plant Cell Rep . 1989; 7:622-625.

88. Msogoya T, Kayagha H, Mutigitu J, Kulebelwa M, Mamiro M. Identification and management of microbial contaminants of banana in vitro cultures. J Appl Biol. 2012; 55:3987-3994

89. Sharma P, Sarma KP. In vitro propagation of Bambusa balcooa for a better environment. In: International Conference on Advances in Biotechnology and Pharmaceutical Sciences (ICABPS'2011) Bangkok Dec. 2011, pp. 248-252

90. Negi D, Saxena S. In vitro propagation of Bambusa nutans Wall. ex Munro through axillary shoot proliferation. Plant Biotechnol Rep. 2011; 5:35-43.

91. Brar J, Anand M, Sood A. In vitro seed germination of economically important edible Dendrcalamus membranaceus Munro. Indian journal of experimental biology .2013; 51:88-96. 
Endophytic bacterial contamination in vitro

92. Yasodha R, Kamala S, Kalaiarasi K. Anatomical and Biochemical Changes Associated with In Vitro Rhizogenesis in Dendrocalamus giganteus. J. Plant Biochemistry \& Biotechnology. 2010; 19(2): 217-222.

Received: February 03, 2016; Accepted: July 14, 2016 


\section{Erratum}

In Article "Biotic Contamination and Possible Ways of Sterilization: A Review with Reference to Bamboo Micropropagation.", with the number of DOI:

http://dx.doi.org/10.1590/1678-4324-2016160485, publish in journal Brazilian Archives of Biology and Technology, vol. 60, the page 1.

In the 01 page, that read:

"http://dx.doi.org/10.190/1678-4324-2016160485"

\section{Read:}

“http://dx.doi.org/10.1590/1678-4324-2016160485" 